\title{
NÚClEO dE EduCAÇÃo Musical E ARTES: A INTERAÇÃO DOS ALUNOS DO MUNICÍPIO DE CAUCAIA (CE) COM A MÚSICA DENTRO E FORA DA ESCOLA
}

\author{
Music and Arts Education Nucleus: students \\ interaction from municipality of Caucaia (CE) \\ with the music inside and outside school
}

\author{
Núcleo de Educación Musical y Artes: la \\ interacción entre los alumnos de la ciudad de \\ Caucaia(CE) y la música dentro y fuera de la \\ escuela
}

\author{
Daniel do Nascimento Sombra \\ Prefeitura Municipal de Caucaia \\ d.sombra@gmail.com \\ ISRAEl KleBer De Oliveira Teófilo \\ Prefeitura Municipal de Caucaia \\ musico.israeloliveira@gmail.com
}

\begin{abstract}
Resumo: Este artigo apresenta dados obtidos através de uma pesquisa realizada com alunos da educação básica do município de Caucaia (CE) com o objetivo geral de conhecer a relação dos alunos do ensino fundamental com a música. Os dados foram analisados através das lentes dos conceitos de campo, habitus e capital, de Pierre Bourdieu. Além disso, investiga o papel da escola no aprofundamento do protagonismo de nossos alunos no seu desenvolvimento artístico-musical, não se limitando ao consumo de música, mas analisando caminhos para estabelecer um diálogo entre a música consumida fora da escola e o fazer artístico-musical no campo da educação básica, por meio do desenvolvimento das dimensões da musicalidade apresentadas por Houlahan e Tacka. São evidenciadas as influências da família, das instituições religiosas e das ferramentas de streaming atuais. Destaca-se o papel do educador musical como possível protagonista ao interligar o desenvolvimento das dimensões da musicalidade das crianças e dos adolescentes às possibilidades que estão incorporadas no habitus dos alunos de forma convidativa, acolhedora, dialógica e significativa. Participaram da pesquisa 2.137 alunos, dos quais 1.395 eram dos anos finais e 742, dos anos iniciais. Os dados foram obtidos com o uso de questionários. Esperamos que os dados possam contribuir nas reflexões acerca do papel da música ou, mais precisamente, do consumo dessa linguagem artística em outras interações dos alunos para além da escola no desenvolvimento das suas dimensões da musicalidade.
\end{abstract}

Palavras-chave: Núcleo de Educação Musical e Artes. Saberes preexistentes. Música na escola. Dimensões da musicalidade.

\begin{abstract}
This article presents data obtained through a research carried out with students of basic education in the municipality of Caucaia (CE) with the general objective of knowing the relationship of elementary school students with music. The data were through the lens of the concepts of field, habitus and capital by Pierre Bourdieu. In addition, it investigates the role of the school in deepening the role of our students in their artistic-musical development, not limited to the consumption of music, but analyzing ways to establish a dialogue between music consumed outside of school and artistic-musical making in the field of basic education, through the development of the dimensions of musicianship, by Houlahan and Tacka. They are evidenced as influences from the family, religious institutions and current streaming tools. The role of the music educator is highlighted as a possible protagonist by linking the development of the dimensions of musicianship of children and adolescents with possibilities that are incorporated in the students' habitus in an inviting, welcoming, dialogic
\end{abstract}


and meaningful way. 2,137 students participated in the research, 1,395 in the final years and 742 in the early years. The data were obtained through questionnaires. We hope that the data can contribute to the reflections about the role of music or more precisely the consumption of this artistic language in other interactions of students besides the school in the development of their dimensions of musicianship.

Keywords: Nucleus of Music Education and Arts. Pre-existing knowledge. Music at school. Dimensions of musicianship.

Resumen: Este artículo nos presenta datos obtenidos a partir de una investigación realizada con alumnos de la enseñanza básica de la ciudad de Caucaia (CE) con el objetivo general de conocer la relación entre los alumnos de la escuela primaria y la música. Los datos fueron analizados a través las lentes de los conceptos del campo, habitus y capital de Pierre Bourdieu. Además de eso, investiga el papel de la escuela en la profundización del protagonismo de nuestros alumnos en su desarrollo artístico musical, no limitándose al consumo de música, pero analizando caminos para establecer diálogo entre la música oída fuera de la escuela y el hacer artístico musical en el campo de la enseñanza básica, por medio del desarrollo de las dimensiones de la musicalidad presentadas por Houlahan y Tacka. Se evidencian influjos de la familia, de las instituciones religiosas y de las herramientas de streaming actuales. Se destaca el papel del educador musical como posible protagonista al interconectar el desarrollo de las dimensiones de la musicalidad de los niños y de los jóvenes a las posibilidades que se añaden en los habitus de los alumnos de forma atractiva, acogedora, dialógica y significativa. Participaron de la investigación 2.137 alumnos de los cuales 1.395 estaban en los años finales y 742 en los iniciales. Los datos fueron obtenidos con el uso de cuestionarios. Esperamos que los datos puedan contribuir en las reflexiones sobre el papel de la música o, más precisamente, del consumo de ese lenguaje artístico en otras interacciones de los alumnos para más allá de la escuela en el desarrollo de las dimensiones de la musicalidad

Palabras clave: Núcleo de Educación Musical y Artes. Saberes preexistentes. Música en la escuela. Dimensiones de la musicalidad.

\section{INTRODUÇÃO}

As primeiras motivações que originaram este trabalho surgiram a partir das reflexões sobre a atuação do Núcleo de Educação Musical e Artes, que está vinculado à Diretoria de Ensino da Secretaria Municipal de Educação, Ciência e Tecnologia de Caucaia (CE) - SMECT. O contexto de criação desse núcleo se deu no início do mês de março de 2020. Seus objetivos iniciais estavam focados em apoiar o ensino de arte no campo da educação básica tanto no regime de turno como no regime de contraturno, uma vez que o municipio possui professores específicos de música que atuam, em sua maioria, no contraturno. Ficaria a cargo do núcleo a orientação das ações artísticas dentro de projetos extracurriculares específicos, a formação continuada em arte para os professores dos anos iniciais e anos finais, e ainda a articulação para a possível criação de uma escola de música municipal.

Dessa forma, para iniciar as ações do núcleo, principalmente no contexto de isolamento social, resolvemos partir de uma série de levantamentos para que pudéssemos conhecer os agentes envolvidos no processo de ensino e aprendizagem de arte e/ou música nos anos iniciais e finais, tanto professores quanto alunos. Também realizamos pesquisas com os alunos para compreender de que forma eles interagiam com as diversas linguagens artísticas, tanto em termos de consumo quanto em termos de fazer artístico, e em que locais se davam essas interações.

A partir dos levantamentos prévios, o Núcleo de Educação Musical e Artes pôde delinear uma série de ações para oferecer suporte pedagógico aos professores, focando na Unidade Temática Música dentro do Componente 
Curricular Arte nesse primeiro momento. Algumas das ações desenvolvidas foram: criação de grupos de WhatsApp com os professores para interação e troca de informações e vivências; reuniões sincronas com os professores via aplicativos de videoconferência para diálogo e apresentação da linha de trabalho proposta pelo núcleo; uma série de sete videoaulas sobre música para os alunos, elaboradas a partir das habilidades propostas pela Base Nacional Comum Curricular - BNCC (Brasil, 2017), gravadas e disponibilizadas no YouTube, além de material complementar disponibilizado nos grupos de WhatsApp, com possibilidade de adaptação dos professores para a sua própria realidade.

Visto a quantidade de ações e os vastos entendimentos e referenciais que ajudaram o núcleo a trilhar tais caminhos, não seria viável discorrer sobre todos eles em um único texto. Portanto, optamos por trazer, neste trabalho, um recorte sobre uma das ações acima citadas. A saber, o levantamento sobre as interações dos alunos com a música e com o fazer musical. Acreditamos que, para este momento, é interessante contribuir com as reflexões acerca da música do cotidiano e a música da escola, buscando assim trazer visões menos homogeneizadas da escola e do fazer musical nela inserido, partindo dos saberes preexistentes de nossos alunos.

Dessa forma, temos como questão geradora: de que forma os alunos do ensino fundamental de Caucaia se relacionam com a música no seu cotidiano dentro e fora da escola? Temos como objetivo geral conhecer a relação dos alunos do ensino fundamental de Caucaia com a música no seu cotidiano, dentro e fora da escola, e como objetivos específicos: analisar as formas de consumo musical dos estudantes e as instituições envolvidas nessa interação; compreender a relação dos alunos com o fazer musical; e analisar o papel da escola nas relações de interação com música por parte dos alunos.

A seguir, discorreremos sobre as teorias que lançam luz em nosso entendimento e nos ajudam a compreender tais relações entre os alunos e a música.

\section{FUNDAMENTAÇÃO TEÓRICA}

Utilizamos os conceitos de habitus, campo e capital de Pierre Bourdieu a partir da perspectiva de Setton (2002) e Maton (2018); das dimensões da musicalidade apresentadas por Houlahan e Tacka (2015) com base nas contribuições de Sombra (2018); por fim, discutimos os pressupostos da relação entre os alunos e a música empregando as contribuições de Arroyo (2007) para articular as reflexões apresentadas no presente artigo.

\section{Habitus, campo e capital}

Setton (2002) apresenta habitus como um conceito para além de destino, de forma a orientar, consciente ou inconscientemente, os agentes em definição de suas escolhas ou ações, nos permitindo identificar socialmente os individuos na contemporaneidade. De acordo com Bourdieu (2007, p. 97 apud Maton, 2018, p. 76), a teoria da prática precisa da equação: “[(habitus)(capital)] + campo = prática", em que habitus pode ser entendido como as disposições 
preestabelecidas dentro da complexidade desse sistema no qual estamos situados. Por sua vez, capital é o que nos determina enquanto situação dentro desse sistema e são identificadas quatro formas de capital na teoria, sendo elas: econômico (traduzido na forma de bens materiais), cultural (originário do conhecimento e experiências estéticas), social (tendo como base a herança familiar e cultural) e simbólico (poder que representa e pode ser convertido em outras formas de capital). Já o campo é onde acontecem as interações, transações e eventos sociais em busca, principalmente, do acúmulo de capitais.

Utilizamos esses conceitos como embasamento para identificar o habitus dos alunos relacionado à interação com a música e sua articulação nos campos familiar e social e buscamos identificar o capital cultural em articulação com as possibilidades de realização no campo da educação básica e no subcampo da educação musical, como apontado por Sombra (2018).

\section{Dimensões da musicalidade}

Houlahan e Tacka (2015) incluem como dimensões da musicalidade: performance, alfabetização musical e habilidades de pensamento crítico, criatividade e escuta, assim como administração da herança musical e cultural regional. Para analisarmos os dados obtidos na pesquisa, precisamos apresentar todas as dimensões de forma a contextualizar o leitor sob a perspectiva do desenvolvimento das dimensões da musicalidade como proposta de abordagem dos autores em suas proposições. Tais proposições nos ajudam a compreender quais dimensões da musicalidade estão sendo desenvolvidas pela escola e/ou pelas outras instituições sociais nas quais os alunos estão envolvidos, por meio da sua interação com a música.

A performance seria a base do programa musical, interligando o canto, movimentos, execução instrumental e regência, e destacando o canto como protagonista pelo dinamismo da internalização do som e a emissão imediata.

A alfabetização musical interliga habilidades do pensamento crítico ao abrir caminhos para o desenvolvimento do aluno no mundo da música, em que várias estratégias se concatenam por meio das habilidades de leitura e escrita musical, de modo a ampliar sua percepção e entendimento musicais.

Houlahan e Tacka (2015) apresentam o direcionamento da criatividade de maneira orientada durante a realização musical, por meio da composição e da improvisação, de forma a atentar ao contexto musical no qual o aluno está inserido e à necessidade de contextualização com atividades na prática de sala de aula.

Ao motivarmos a escuta por parte do aluno, oferecendo uma escuta guiada e diversificada, como apresentada por Houlahan e Tacka (2015), podemos contextualizar o aluno de forma a entender elementos basilares da música no contexto cultural e contribuir na formação do seu gosto musical diversificado e consciente.

A administração da herança musical e cultural regional, destacada por Houlahan e Tacka (2015), ressalta a importância do papel das canções tradicionais que Mills aborda: 
Nem mesmo a mais excelente criação individual pode ser um substituto para as tradições. Escrever uma música folclórica está muito além dos limites dessa possibilidade, como escrever um provérbio. Assim como um provérbio condensa séculos de sabedoria popular e observação, assim, nas canções tradicionais, as emoções de séculos são imortalizadas na elegante forma da perfeição. Nenhuma obra-prima pode substituir tradições (Mills, 1991, p. 121 apud Houlahan; Tacka, 2015, p. 21, tradução nossa).

Devemos salientar o papel da criança como entusiasta da arte que Kodály apresenta como pura em Houlahan e Tacka:

Vamos parar com a superstição dos professores sobre o fato de que somente adaptações de arte de forma diluída são suscetíveis aos propósitos do ensino. Uma criança é a plateia mais suscetivel e mais entusiasta para a arte pura; pois em cada grande artista, a criança está viva - e isso é algo sentido pelo agradável espírito da juventude. Por outro lado, somente arte de valor intrínseco é suscetivel para as crianças! Todo o resto é prejudicial. Além do que, a comida é mais cuidadosamente escolhida para uma criança do que para um adulto. Nutrição musical, que é "rica em vitaminas", é essencial para as crianças (Kodály, 1974, p. 122 apud Houlahan; Tacka, 2015, p. 22, tradução nossa).

Sombra (2018) aponta a ligação de cada uma das dimensões do conhecimento artístico com todas as dimensões da musicalidade ao percebermos as dimensões do conhecimento artístico apontadas pela BNCC (Brasil, 2017) como relacionadas ao campo da educação básica, e as dimensões da musicalidade mais direcionadas ao subcampo da educação musical.

\section{As relações sociais com a música}

Nos últimos anos, vários estudos realizados no âmbito da sociologia da música apresentaram o espaço que ela tem ganhado nas culturas juvenis: "A música é de importância central na vida da maior parte dos jovens, cumprindo necessidades sociais, emocionais e cognitivas" (North; Hargreaves; O’Neill, 2000, p. 269 apud Arroyo, 2007, p. 14). Além das funções e/ou usos que a música tem em suas vidas, podemos destacar que são vários os espaços que proporcionam essa interação entre os alunos e a música, e, por conseguinte, cada espaço oferece manifestações e oportunidades próprias. Entre tais espaços podemos destacar três instituições sociais que consideramos mais expressivas: a família, a escola e a igreja. Em consonância com a lógica de cada espaço, os jovens são levados a não só ouvir, mas também fazer música de acordo com as regras do campo em questão. $\mathrm{O}$ fato é que alguns desses ambientes revelam mais oportunidades do que outros, o que nos leva a refletir sobre as possibilidades de equilibrar as interações independentemente 
dos espaços, levando-os, assim, ao pleno desenvolvimento das dimensões da musicalidade citadas anteriormente.

Outro fator que consideramos importante destacar é que as formas de interagir e se apropriar da música vêm se modificando consideravelmente por meio dos avanços tecnológicos e das mídias digitais, cada vez mais presentes no espaço social juvenil. Segundo Teófilo (2019), a música faz parte da rotina diária dos alunos e está presente até mesmo nas atividades mais básicas, como escovar os dentes, tomar banho, estudar e se alimentar.

Vale lembrar também que a música tem um forte papel de formação e identificação dentro das culturas juvenis. Segundo Mueller (2002, p. 595 apud Arroyo, 2007, p. 17), "[...] o gosto musical e as práticas culturais servem para definir as identidades sociais e culturais das pessoas e marcar sua distinção de outros grupos sociais". Vários grupos sociais acabam por receber nomes de gêneros musicais e outros possuem gêneros musicais homônimos. Isso acontece porque tais grupos compartilham, além de manifestações sonoras, modos de vestir, falar, consumir e pensar.

\section{Metodologia}

Este artigo apresenta dados referentes a uma pesquisa realizada pelos seus autores no municipio de Caucaia, contando com 2.137 interações de alunos de ambos os sexos, dos quais 1.395 eram dos anos finais ( $6^{\circ}$ ao $9^{\circ}$ ano) e 742 , dos anos iniciais ( $1^{\circ}$ ao $5^{\circ}$ ano). Tal pesquisa buscou conhecer a relação dos alunos do ensino fundamental de Caucaia com a música no seu cotidiano dentro e fora da escola. Foram levados em consideração fatores como a influência da familia e dos lugares que os estudantes frequentam, destacando-se o papel da escola. Na escola pode haver um estreitamento entre a educação musical, o ensino de música, o consumo de música de forma consciente e a utilização da música em um cotidiano escolar. Acreditamos que essa interação colabora no desenvolvimento do gosto musical diversificado dos futuros cidadãos, tendo em vista os conceitos de dimensões da musicalidade apresentados por Houlahan e Tacka e a filosofia de educação musical de Kodály.

Várias pesquisas foram realizadas a respeito do ensino de música, da educação musical e da utilização da música na educação básica, e muito se buscou definir, mas qualquer ação que envolve a diversidade da contemporaneidade e, mais especificamente, a infância e a juventude de nosso povo, estando essa ação relacionada à educação básica, precisa se perceber na nova realidade em que nos encontramos.

Conhecer os alunos e interagir com eles é primordial para embasar nossa atuação, tendo em vista o habitus interiorizado por eles, e para formar uma ideia do capital cultural dos quais eles são detentores, pois, como afirma Fonterrada (2008, p. 10), "no entanto, após tanto tempo de ausência, perdeu-se a tradição; a música não pertence mais à escola e, para que volte, é preciso repensar os modos de implantação de seu ensino e de sua prática”. Dessa forma, o questionário aderido ilumina caminhos e apresenta a interação da música com os alunos do município de Caucaia, valorizando 
seus saberes preexistentes e suas interações em outros campos para além da educação básica.

Os questionários foram enviados aos professores por meio do Núcleo de Educação Musical e Artes e eles, por sua vez, os encaminharam aos seus alunos. Foram elaborados dois questionários, um para os anos iniciais e outro para os anos finais, porém ambos continham as mesmas perguntas. A divisão foi feita para melhor compreensão na análise dos dados por meio do núcleo. Os questionários foram desenvolvidos por nós a partir dos objetivos geral e especificos e sob a luz das teorias já descritas.

O formulário aplicado, tanto para os anos iniciais quanto para os anos finais, contém 30 perguntas, que foram divididas basicamente em cinco seções: identificação, música, dança, artes visuais e teatro. Para este trabalho, analisaremos apenas as respostas das seções de identificação e de música, tendo em vista o foco proposto.

A seção de identificação contém quatro perguntas: nome, data de nascimento, nome da escola e ano em que estuda. O objetivo dessa seção é coletar informações que possam identificar os alunos para gerar um maior entendimento das suas relações quanto à faixa etária (idade e ano escolar) e quanto à localidade (nome da escola). O nome dos alunos foi solicitado para que os professores pudessem analisar as respostas mais facilmente, uma vez que eles tiveram acesso às respostas dos questionários.

A seção de música é a maior seção do formulário, contendo 15 perguntas acerca da interação dos alunos com a música dentro e fora da escola. $\mathrm{O}$ objetivo dessa seção foi conhecer as heranças musicais familiares e, portanto, o habitus primário dos alunos em relação à música. Dessa forma, seguem as quatro primeiras perguntas: sua família escuta música na sua casa? Que tipo ou tipos de música toca na sua casa com maior frequência? Sua família te leva a algum lugar em que toca música? $\mathrm{E}$, por fim, em caso afirmativo os alunos deveriam nomear esses lugares.

Ainda dentro dessa mesma seção, as perguntas seguem com o segundo foco que é o consumo da música por parte dos alunos. O intuito principal é analisar a presença da música no cotidiano dos alunos, compreender suas preferências e influências musicais e descobrir até que ponto isso está atrelado à escola. As perguntas que encerram a seção trazem como ponto central o fazer musical dos alunos e em que lugares essas práticas acontecem com maior frequência, analisando também qual a importância da escola para tais acontecimentos.

A seguir, serão discutidos os gráficos gerados a partir das respostas dos alunos, tendo como base as teorias explicitadas anteriormente.

\section{GRÁFICOS E INTERPRETAÇÕES}

Por meio da análise dos gráficos a seguir, podemos imergir no contexto familiar e pessoal dos alunos dos anos iniciais e finais, além de apreciar os dados relacionados aos papéis das instituições no fazer artístico-musical e na apreciação musical. 


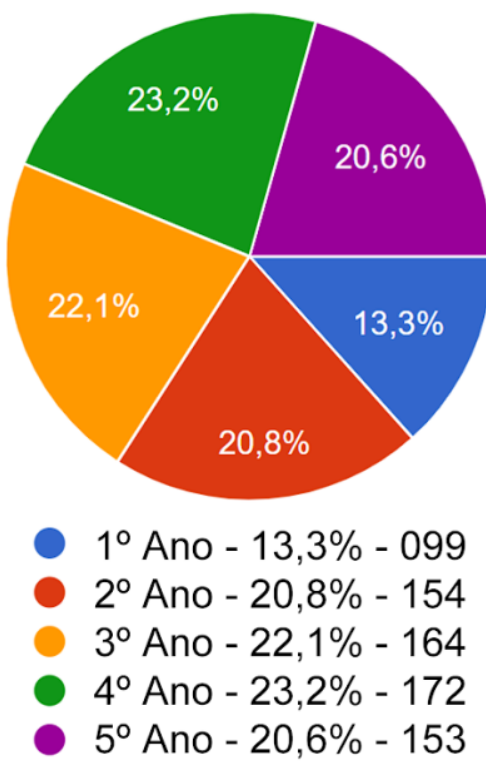

Gráfico 1: Distribuição, entre os anos iniciais, dos alunos que interagiram com o formulário (742 respostas).

Fonte: elaborado pelos autores.

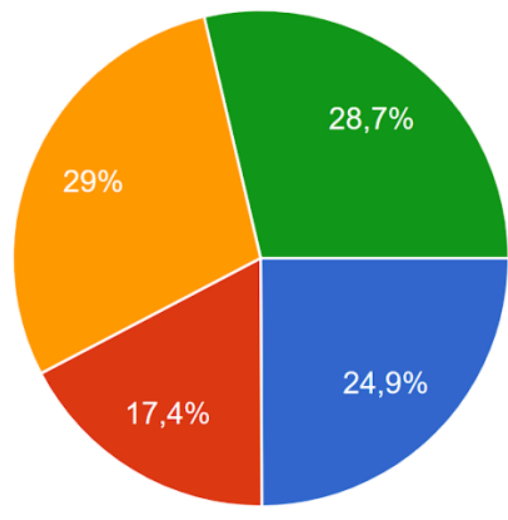

$6^{\circ}$ Ano $-24,9 \%-347$

$7^{\circ}$ Ano $-17,4 \%-242$

$8^{\circ}$ Ano $-29,0 \%-404$

$9^{\circ}$ Ano $-28,7 \%-399$

Gráfico 2: Distribuição, entre os anos finais, dos alunos que interagiram com o formulário (1.392 respostas).

Fonte: elaborado pelos autores.

Percebemos, através dos gráficos 1 e 2, um equilíbrio na divisão entre os anos dos alunos que interagiram com os formulários apresentados. Dessa forma, podemos destacar a representatividade dos segmentos do ensino fundamental.

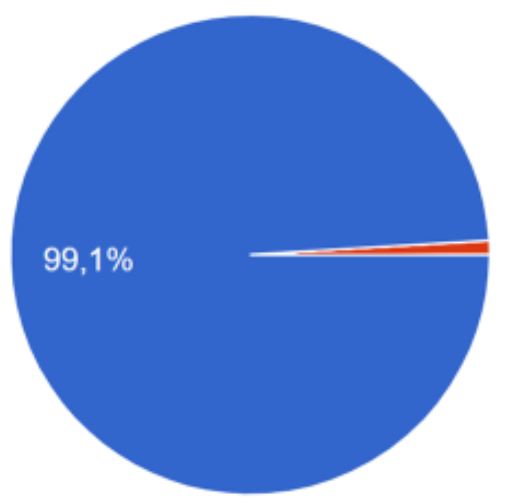

Sim - 99,1\% - 735

Não $-0,9 \%-7$

Gráfico 3: Consumo de música em casa pelas famílias dos anos iniciais. (742 respostas). Fonte: elaborado pelos autores.
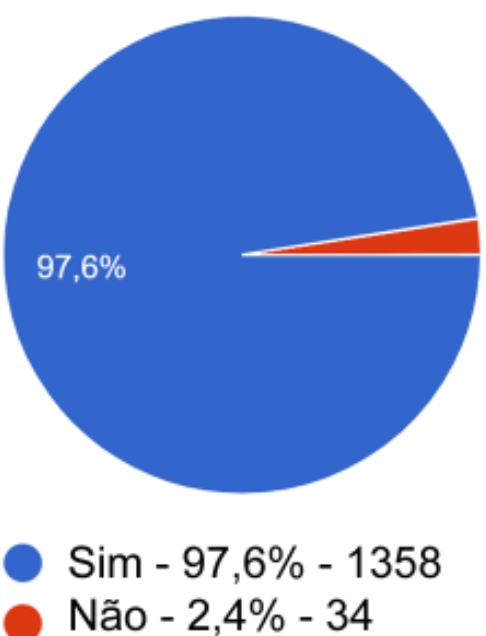

Gráfico 4: Consumo de música em casa pelas famílias dos anos finais. (1.392 respostas). Fonte: elaborado pelos autores. 
Através dos resultados apresentados nos gráficos 3 e 4, podemos notar o papel da família (casa) no desenvolvimento da administração da herança musical e cultural regional dos alunos. De fato, a instituição familiar desempenha um importante papel no habitus primário dos estudantes em relação à música. Constitui-se também um grande locus da escuta musical dos participantes. Sem dúvida, o seio familiar exerce grande influência em nosso gosto musical e na forma como interagimos com a música. Ao nos depararmos com a quantidade de respostas positivas dos alunos, fica inegável a presença da música na instituição familiar e, portanto, nas suas vidas. Isso afirma a ideia de que a educação musical da contemporaneidade não pode desprezar o habitus interiorizado dos discentes, contribuindo, assim, para a administração da sua herança musical e regional, que é uma importante dimensão da musicalidade.

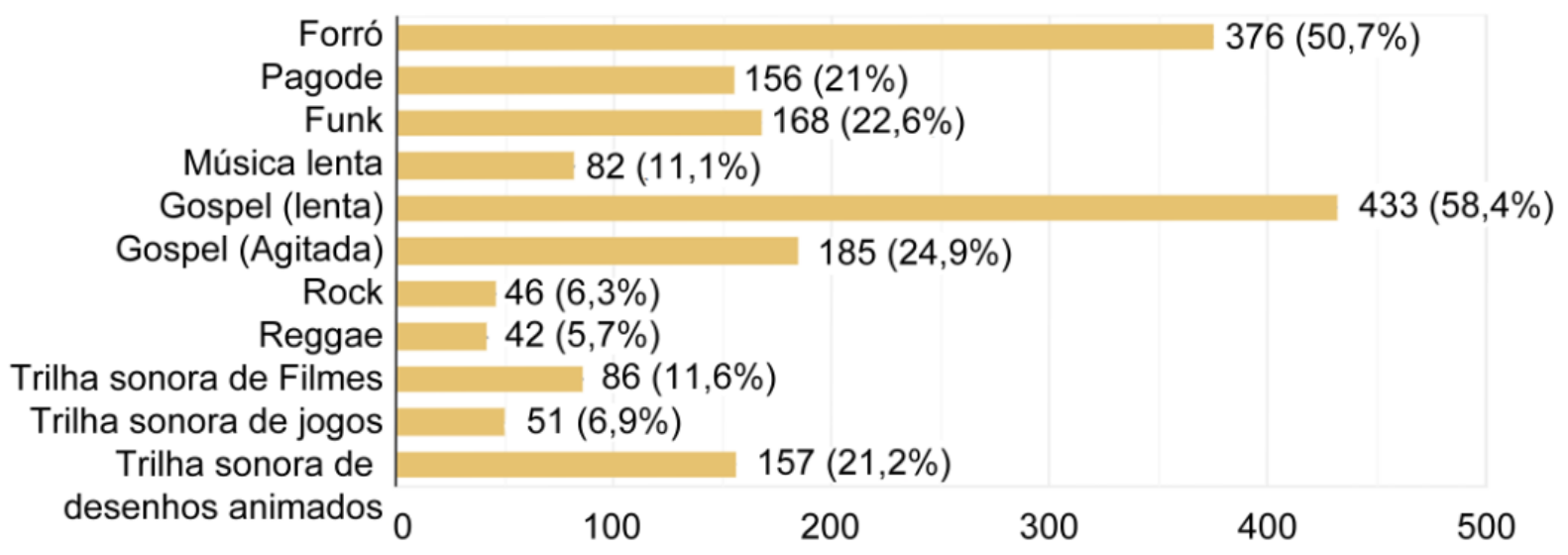

Gráfico 5: Música consumida com maior frequência na casa dos alunos dos anos iniciais. Fonte: elaborado pelos autores.

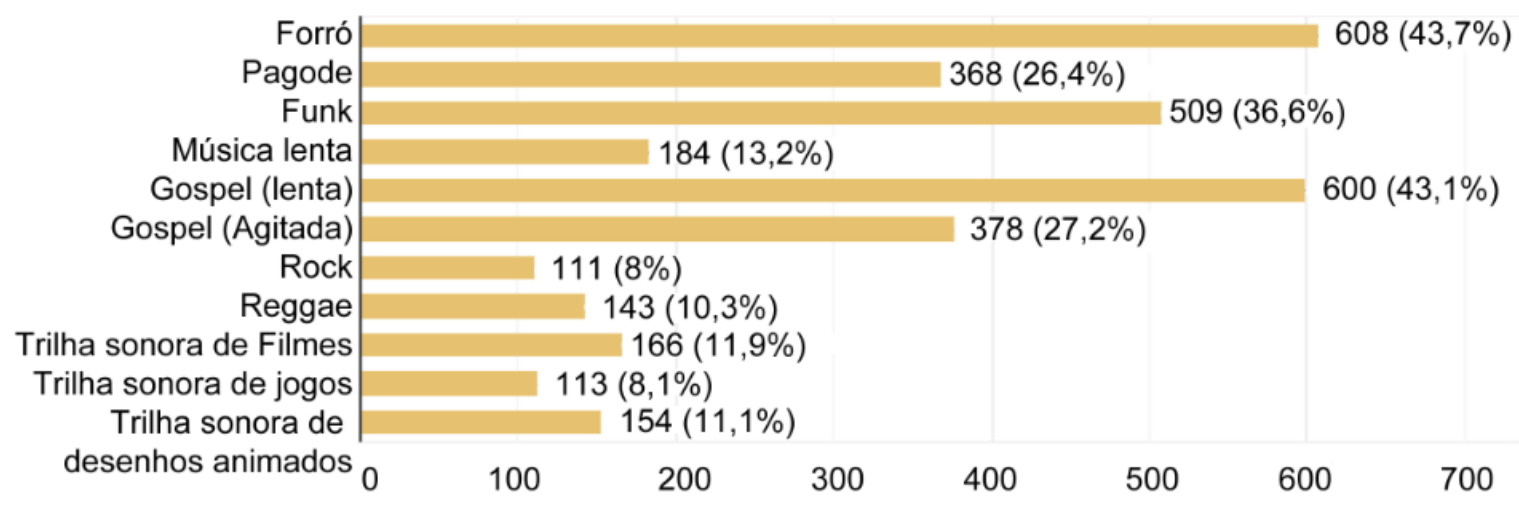

Gráfico 6: Música consumida com maior frequência na casa dos alunos dos anos finais. Fonte: elaborado pelos autores.

Nos anos finais (Gráfico 6), o estilo musical mais escutado nas residências dos alunos é o forró (gênero musical característico da região), seguido de músicas religiosas (igreja), enquanto nos anos iniciais (Gráfico 5) a música gospel é mais executada que o forró. 
Ao analisarmos essa predominância, devemos nos questionar sobre a diversidade do gosto musical de cada aluno que está se desenvolvendo e sobre o papel da escola na promoção dessa diversidade, tendo em vista que o ambiente escolar deveria oportunizar diversas interações artístico-culturais, assim como está escrito na primeira competência específica de Arte para o ensino fundamental na BNCC:

Explorar, conhecer, fruir e analisar criticamente práticas e produções artísticas e culturais do seu entorno social, dos povos indigenas, das comunidades tradicionais brasileiras e de diversas sociedades, em distintos tempos e espaços, para reconhecer a arte como um fenômeno cultural, histórico, social e sensivel a diferentes contextos e dialogar com as diversidades (Brasil, 2017, p. 198).

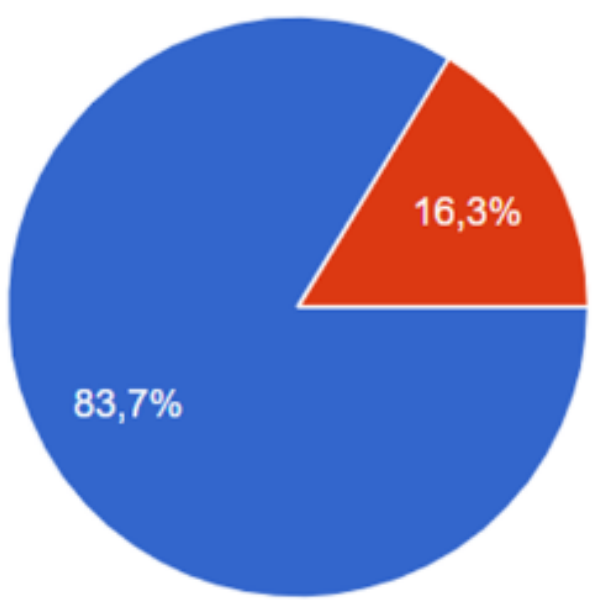

Sim - $621(83,7 \%)$

Não - $121(16,3 \%)$

Gráfico 7: Visitação com a família em ambientes onde músicas são executadas (anos iniciais -742 respostas). Fonte: elaborado pelos autores.

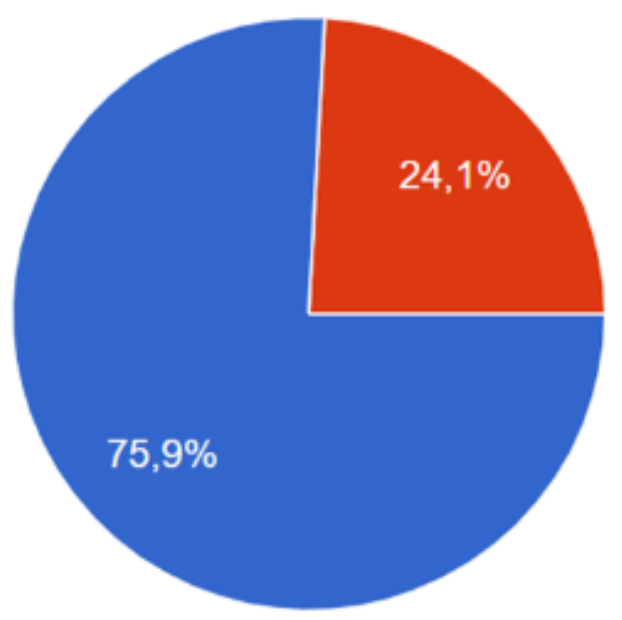

Sim - $1056(75,9 \%)$

- Não - $336(24,1 \%)$

Gráfico 8: Visitação com a família em ambientes onde músicas são executadas (anos finais - 1.392 respostas). Fonte: elaborado pelos autores.

Por meio dos gráficos 7 e 8 podemos perceber que o protagonismo familiar também pode ser identificado através do processo de curadoria do que é escutado fora do ambiente residencial, mas ainda pertence ao campo social no qual a família está inserida. Podemos perceber que o convívio familiar em ambientes externos ao domicílio se reduz quando comparamos anos finais com anos iniciais. 


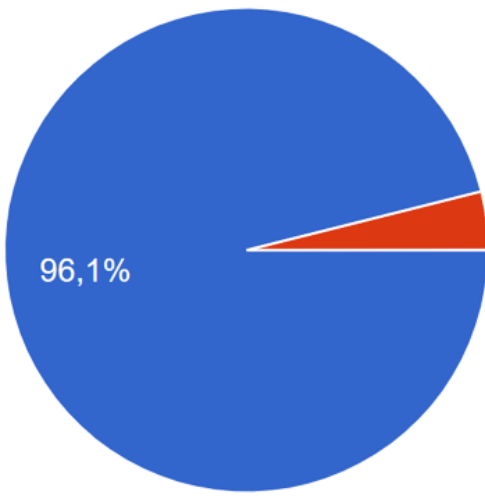

Sim $-713(96,1 \%)$

- Não- $29(3,9 \%)$

Gráfico 9: Consumo de música "Você escuta música?" (anos iniciais -742 respostas). Fonte: elaborado pelos autores.

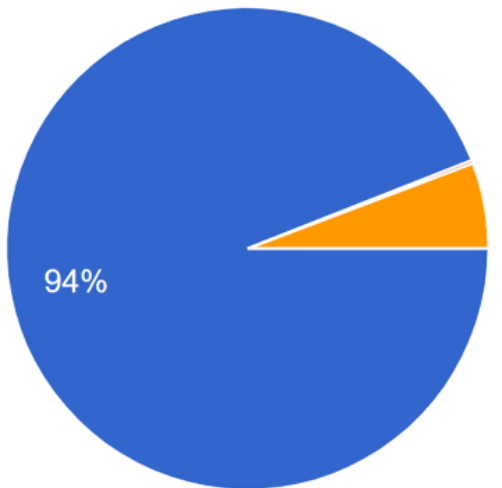

Sim - 1309 (94\%)

- Não muito - $80(5,7 \%)$

Não - $3(0,2 \%)$

Gráfico 10: Consumo de música "Você escuta música?" (anos finais -1.392 respostas). Fonte: elaborado pelos autores.

É possível constatar, por meio dos gráficos 9 e 10, o papel significativo da família na relação dos estudantes com a música ao percebermos seu papel de curadoria não só no convívio do lar, mas também no convívio fora da residência, tanto para os alunos dos anos iniciais quanto para os alunos dos anos finais. Podemos perceber aqui a relação entre a escuta musical no seio familiar e o processo de escuta individual de cada aluno. As porcentagens positivas são muito parecidas, o que nos leva a acreditar na comprovação dessa transferência de habitus entre a família e o aluno.

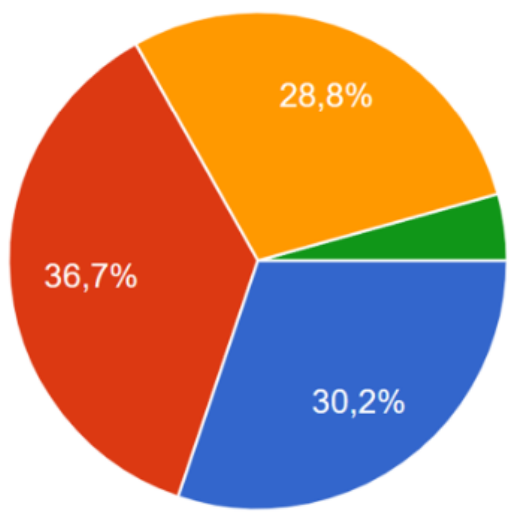

- Muitas vezes durante o dia - $224(30,2 \%)$

- Poucas vezes durante o dia $-272(36,7 \%)$

Nem todo o dia - $214(28,8 \%)$

Só quando vou para lugares - $32(4,3 \%)$ que tocam música

Gráfico 11: Frequência do consumo de música (anos iniciais -742 respostas).

Fonte: elaborado pelos autores.

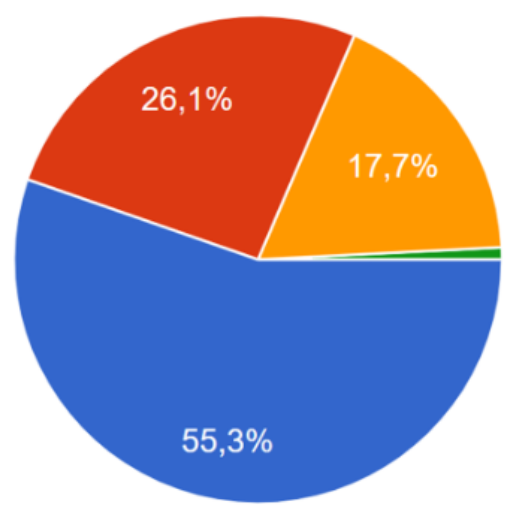

Muitas vezes durante o dia - $770(55,3 \%)$

Poucas vezes durante o dia -364 (26,1\%)

Nem todo o dia - $247(17,7 \%)$

- Só quando vou para lugares - $11(0,8 \%)$ que tocam música

Gráfico 12: Frequência do consumo de música (anos finais - 1.392 respostas).

Fonte: elaborado pelos autores. 
Através dos gráficos 11 e 12, podemos verificar que os alunos dos anos finais escutam música durante mais tempo que os alunos dos anos iniciais, o que acreditamos ser consequência do amadurecimento e da conquista de independência. Outro fator importante é que a música é um elemento identificador das culturas juvenis, como citado anteriormente por Arroyo (2007). Dessa forma, à medida que os alunos ingressam nessas culturas, o consumo da música aumenta.

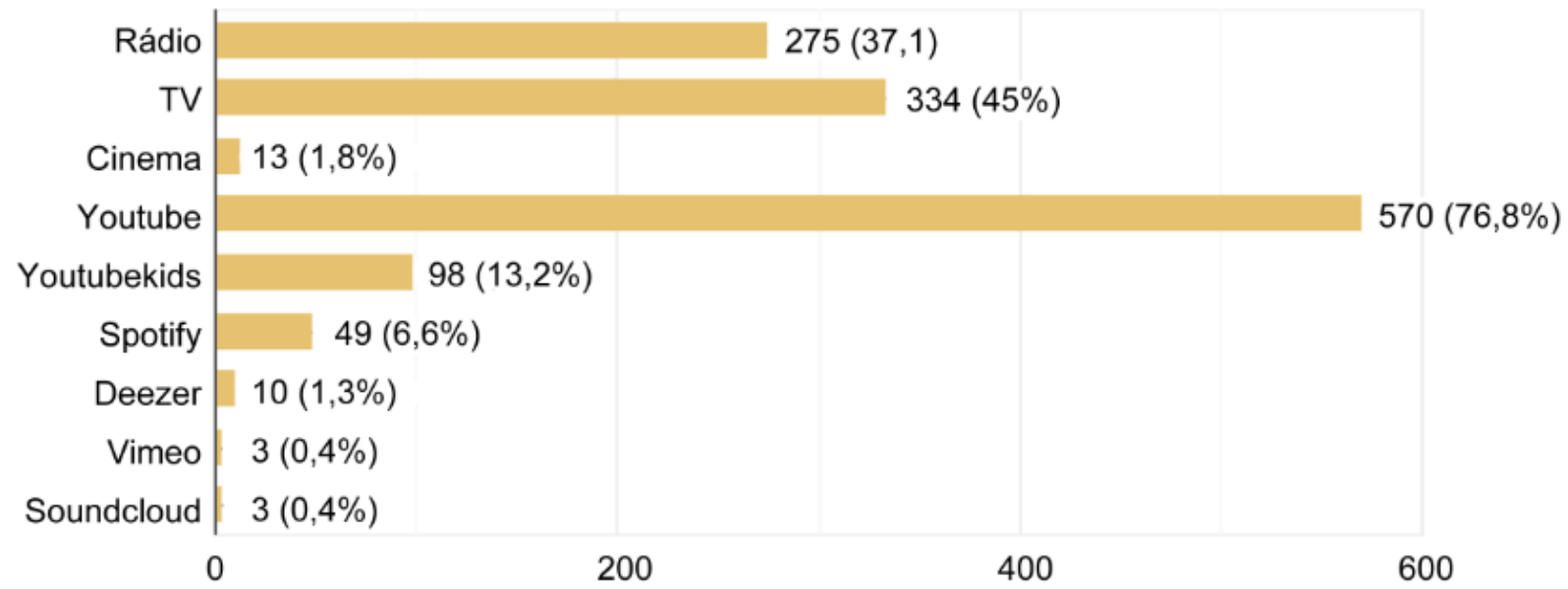

Gráfico 13: Consumo de música online (anos iniciais -742 respostas).

Fonte: elaborado pelos autores.

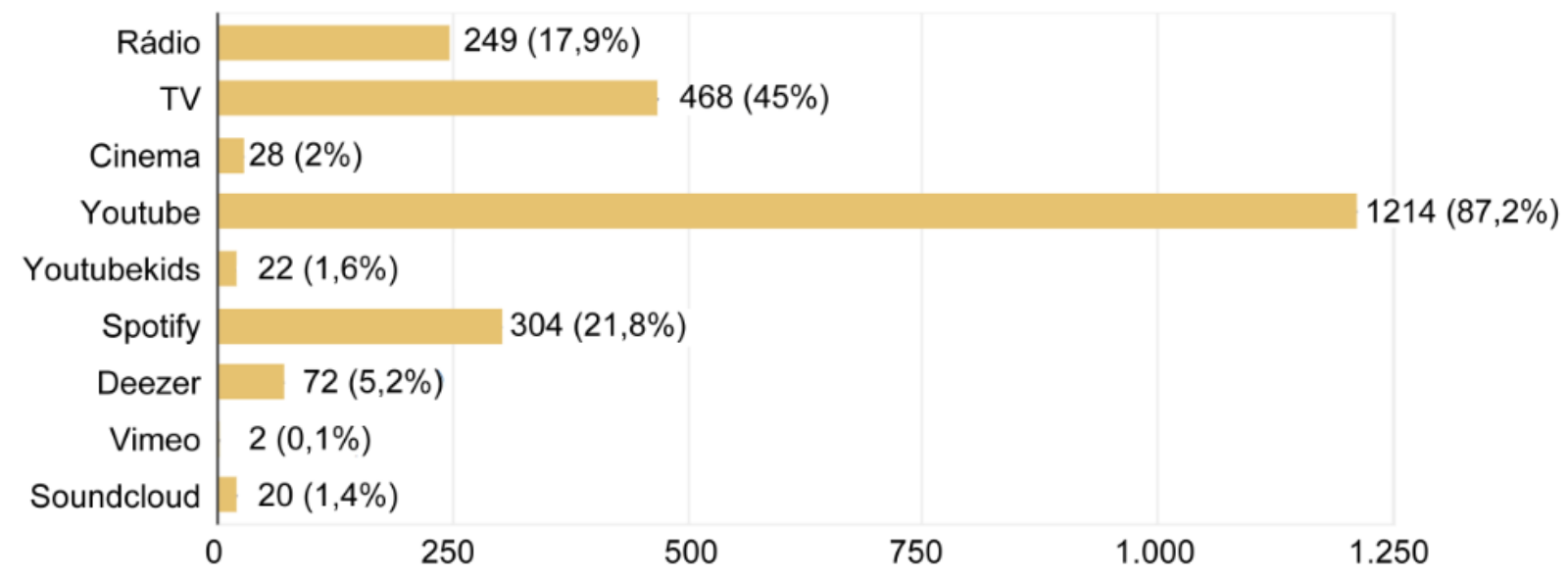

Gráfico 14: Consumo de música online (anos finais - 1.392 respostas). Fonte: elaborado pelos autores. 
Através dos gráficos 13 e 14, é notável o papel do YouTube como ferramenta de streaming mais utilizada pelos alunos. Acreditamos que seja pelo fato de ser uma plataforma em que os alunos têm controle sobre o conteúdo a ser executado de forma gratuita. A partir das respostas abrem-se possibilidades de utilização dessa ferramenta, que, apesar de não ser desenvolvida para o ensino, pode ser usada pelos educadores musicais para o desenvolvimento do gosto musical diversificado, bem como de outras dimensões da musicalidade. Dessa forma, o YouTube faz parte do habitus musical dos alunos, o que deve ser levado em consideração pelos professores que se propõem a trabalhar novas metodologias de ensino de música.

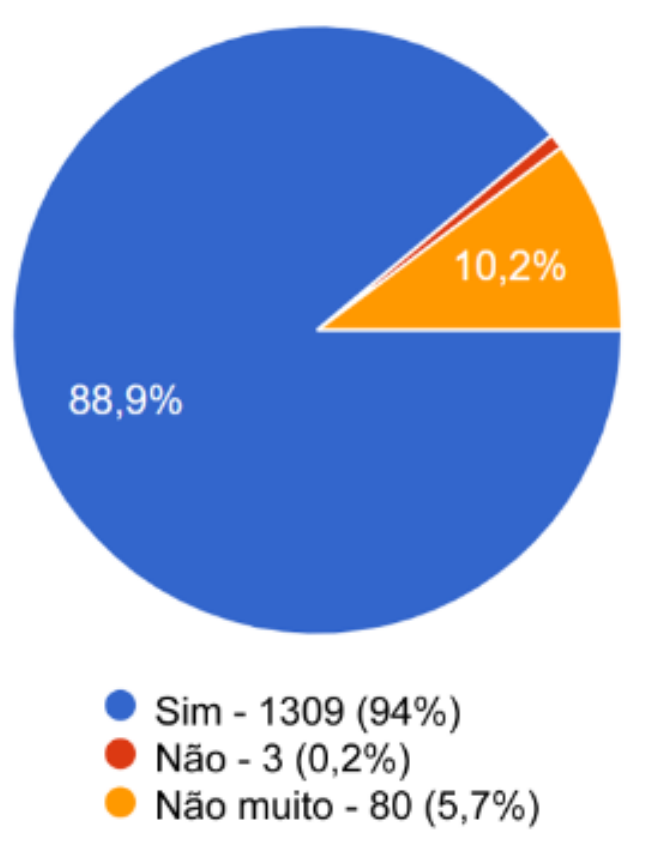

Gráfico 15: Afetividade no consumo de música - "Você gosta de ouvir música?" (anos iniciais -742 respostas). Fonte: elaborado pelos autores.

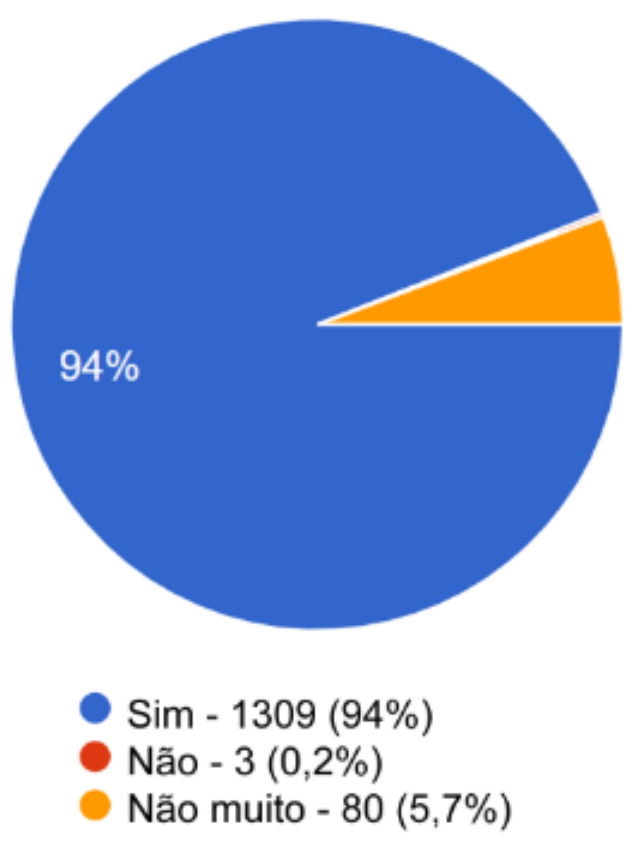

Gráfico 16: Afetividade no consumo de música - "Você gosta de ouvir música?" (anos finais -1.392 respostas). Fonte: elaborado pelos autores.

O vínculo afetivo é claramente percebido através dos gráficos 15 e 16, de modo que é possivel entender o papel de linguagem universal que já atribuímos à música. As respostas mostram como os alunos estão afetivamente ligados à música, não se tratando de uma obrigação, mas sim de um gosto pessoal. Isso confirma também a forte presença da música no cotidiano, influenciando na formação integral dos estudantes. 


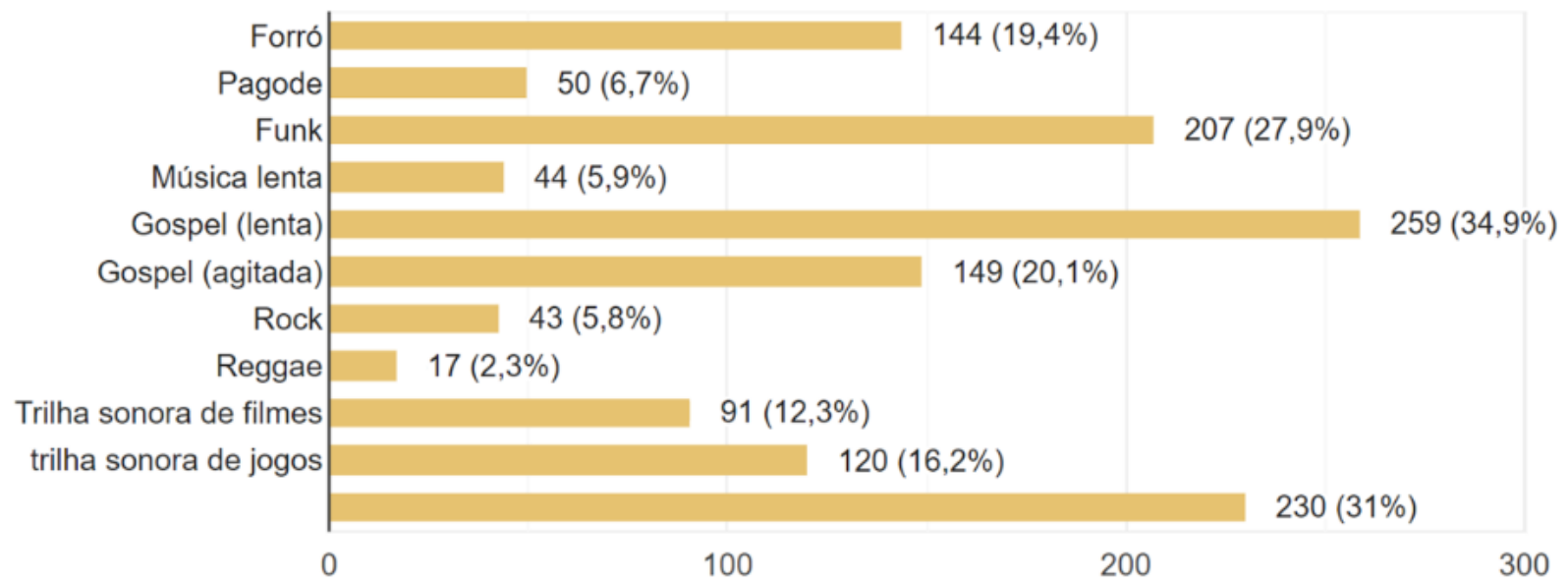

Gráfico 17: Gênero musical mais ouvido (anos iniciais -742 respostas). Fonte: elaborado pelos autores.

No Gráfico 17 acima, verificamos que a música religiosa tem papel de destaque no consumo de música por parte dos alunos dos anos iniciais. Podemos deduzir que o papel da influência familiar está diretamente vinculado a esse resultado, tendo em vista que o tipo de música mais executado nas residências dos estudantes é a música religiosa, como vimos no gráfico anterior. Assim, a força do habitus primário fica ainda mais evidente em relação aos alunos dos anos iniciais, engendrando práticas por meio dessa estrutura estruturada e estruturante que é o habitus.

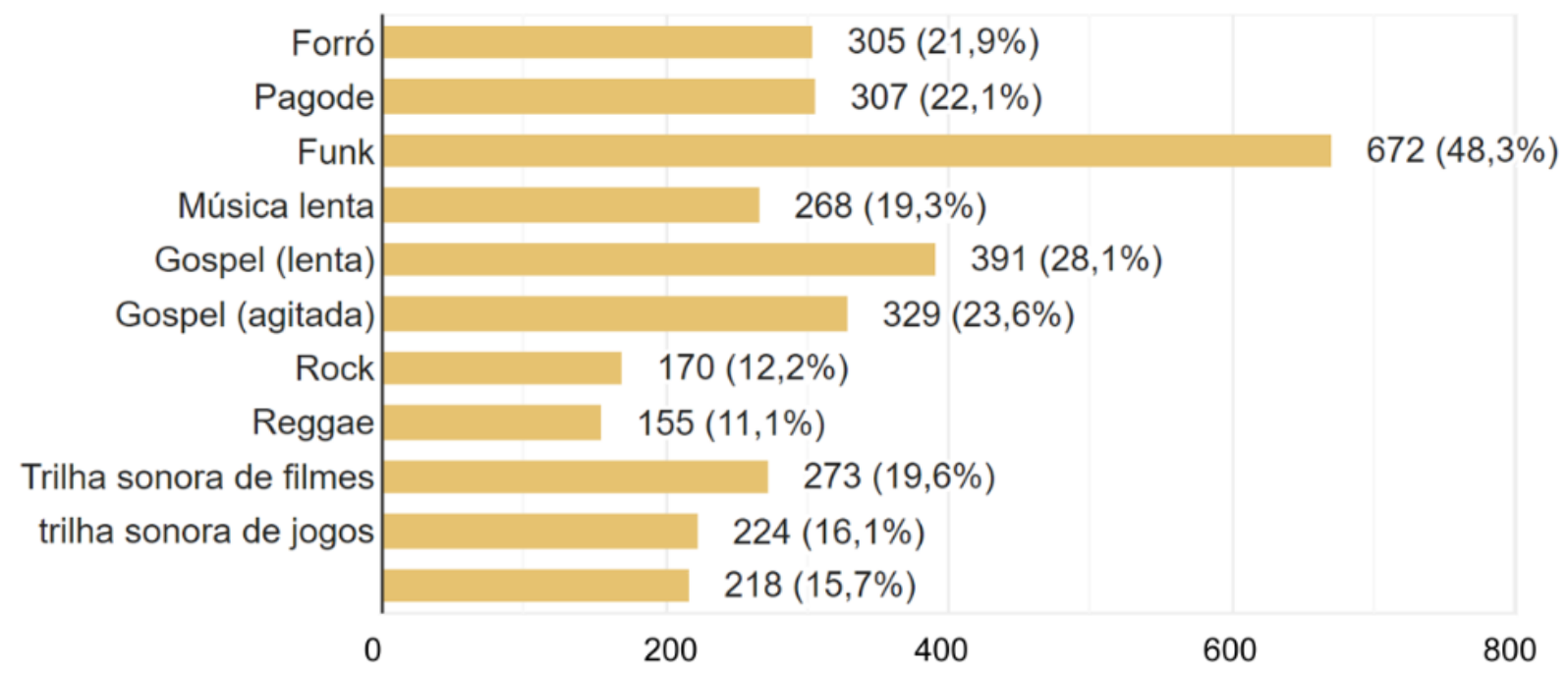

Gráfico 18: Gênero musical mais ouvido (anos finais - 1.392 respostas).

Fonte: elaborado pelos autores. 
Já no Gráfico 18, que se refere aos anos finais, podemos perceber a influência do estilo musical funk assumindo a liderança no consumo de música por parte dos alunos. Tendo em vista o gráfico que aponta o tipo musical forró como o mais executado nas residências desses alunos, podemos levantar uma hipótese acerca do protagonismo dos próprios alunos na escolha do repertório musical consumido, mas acreditamos que seja também uma forma de atuação do campo social no qual esse aluno está imerso. Determinados estilos musicais fazem parte do capital cultural regional e o seu consumo representa um capital simbólico que pode gerar mudanças no habitus ao ser incorporado no cotidiano dos estudantes, por exemplo, com a sua inclusão em grupos sociais em que predomina dada preferência musical.
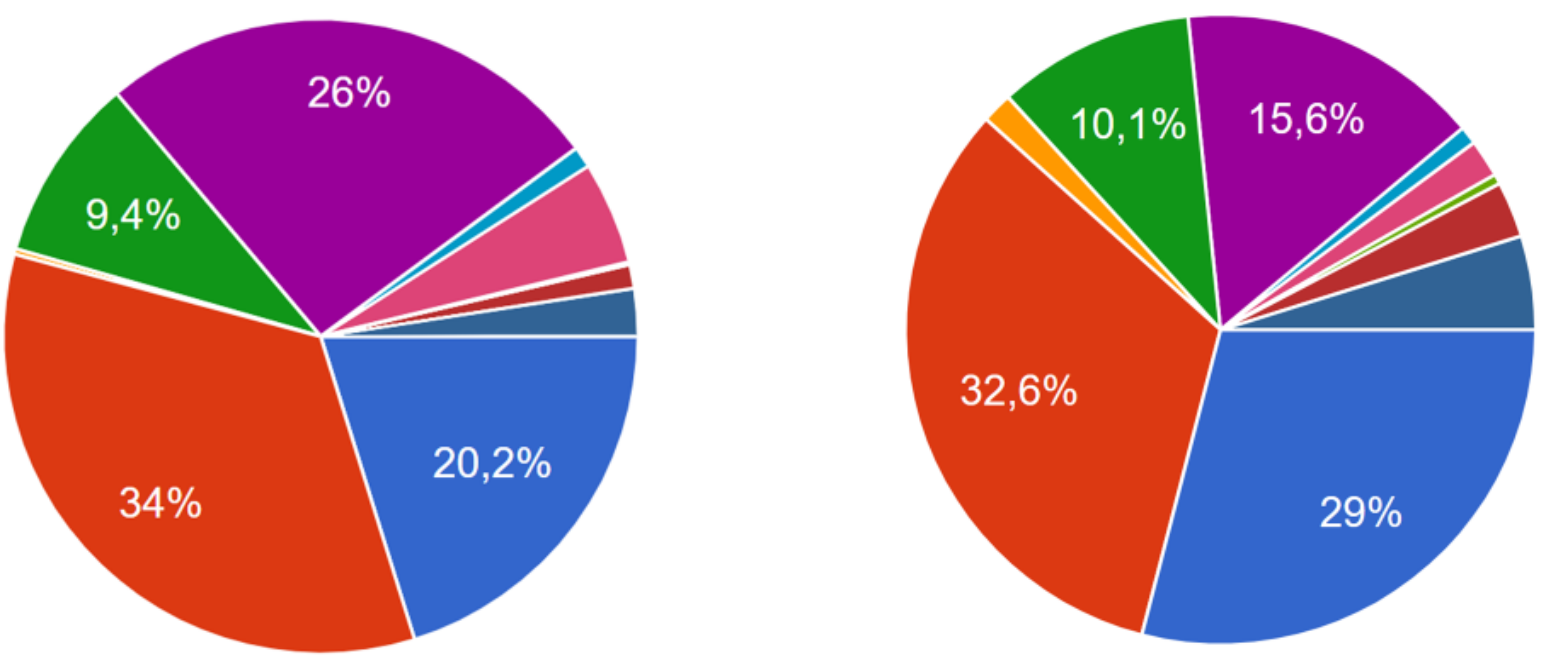

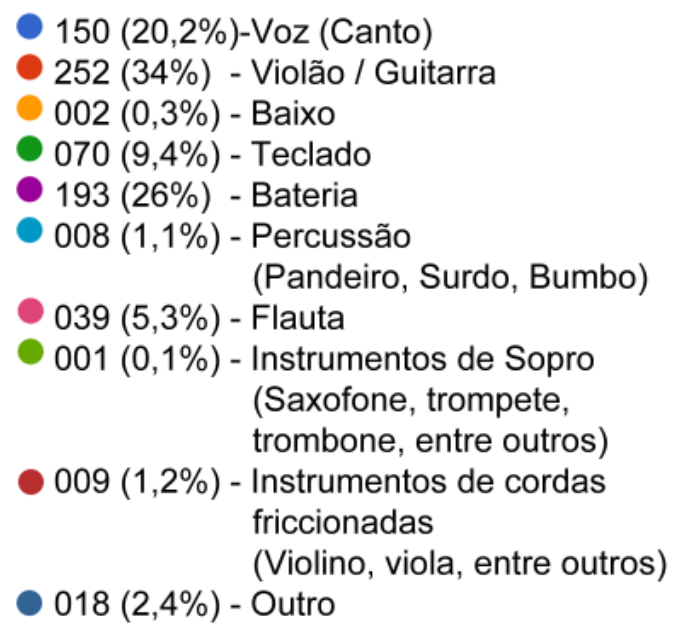

Gráfico 19: Apreciação de instrumento musical (anos iniciais - 742 respostas).

Fonte: elaborado pelos autores.

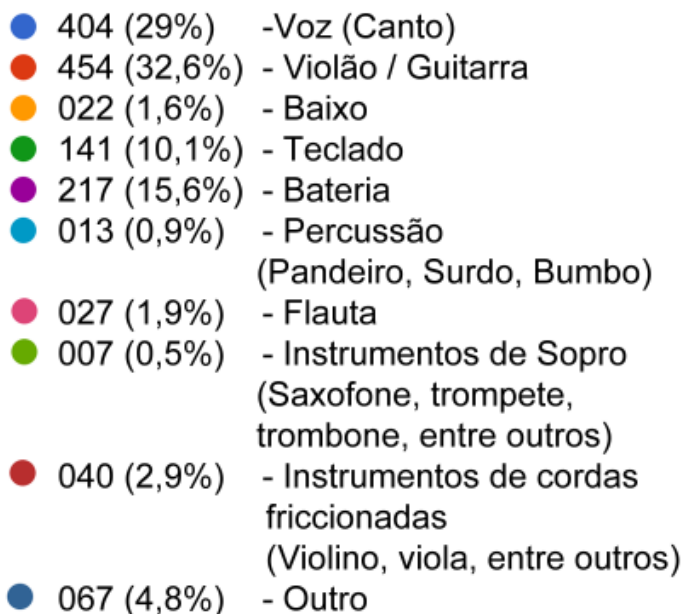

Gráfico 20: Apreciação de instrumento musical (anos finais -1.392 respostas). Fonte: elaborado pelos autores. 
Através dos gráficos 19 e 20, verificamos o papel do instrumento violão e/ou guitarra em destaque, seguido imediatamente pela voz ou canto. Destacamos, então, o papel da música popular, em especial o estilo musical forró e a música religiosa, nos quais esses instrumentos estão fortemente presentes. Acreditamos que a tradição brasileira associada ao instrumento violão e ao papel dos cantadores pode se relacionar com a interação dos alunos na presente pesquisa, o que apontaria um habitus interiorizado por parte deles.

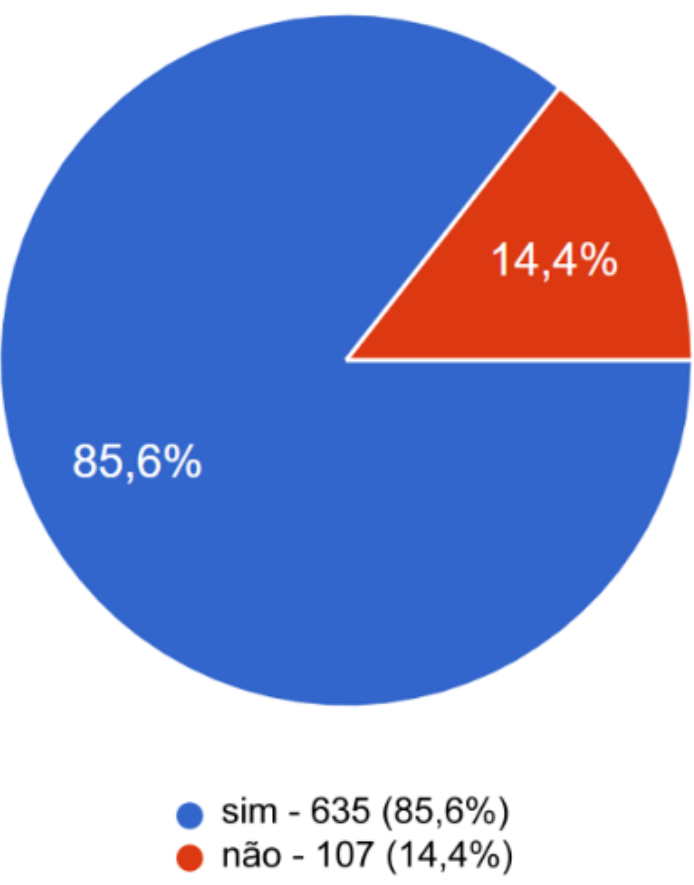

Gráfico 21: O canto e a afetividade "Você gosta de cantar?" (anos iniciais -742 respostas). Fonte: elaborado pelos autores.

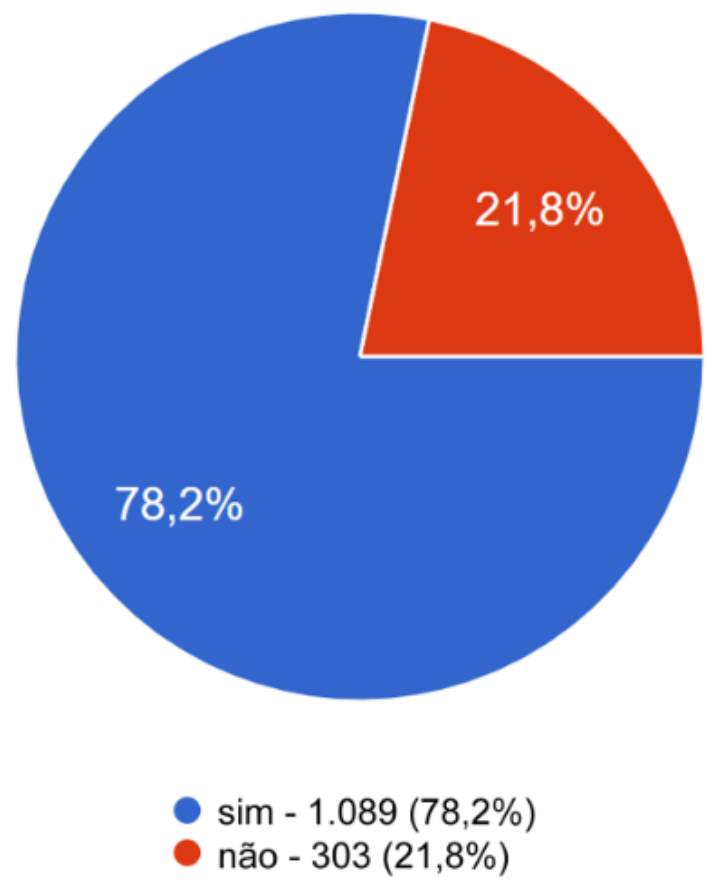

Gráfico 22: O canto e a afetividade "Você gosta de cantar?" (anos finais - 1.392 respostas). Fonte: elaborado pelos autores.

O vínculo afetivo com o canto se manifesta de forma intensa nos gráficos 21 e 22, mas com uma redução nos anos finais quando comparados aos anos iniciais. Podemos, com esses resultados, elaborar ações para que o instrumento voz venha a ter grande representatividade quando utilizamos o canto coletivo durante as aulas do componente curricular Arte. A partir disso, foi possivel direcionar algumas das ações do Núcleo de Educação Musical e Artes de forma a contribuir na difusão do papel de protagonismo da voz nas ações voltadas ao ensino fundamental. Tais respostas reforçam ainda a possibilidade de utilização da voz pelos educadores musicais e quebram paradigmas que ditam que o ensino de música precisa ser necessariamente instrumental. 


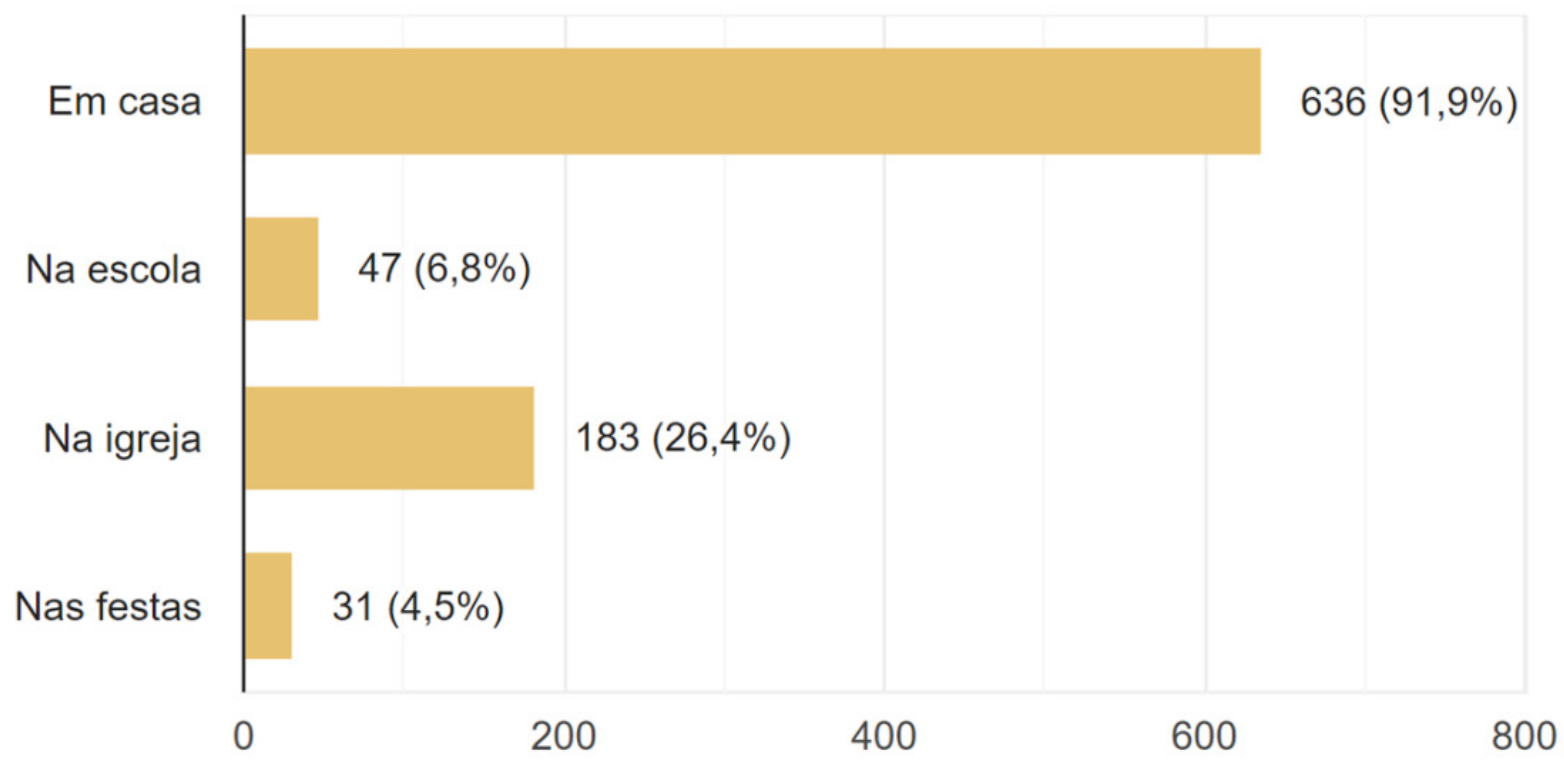

Gráfico 23: Lugar onde canta (anos iniciais - 692 respostas). Fonte: elaborado pelos autores.

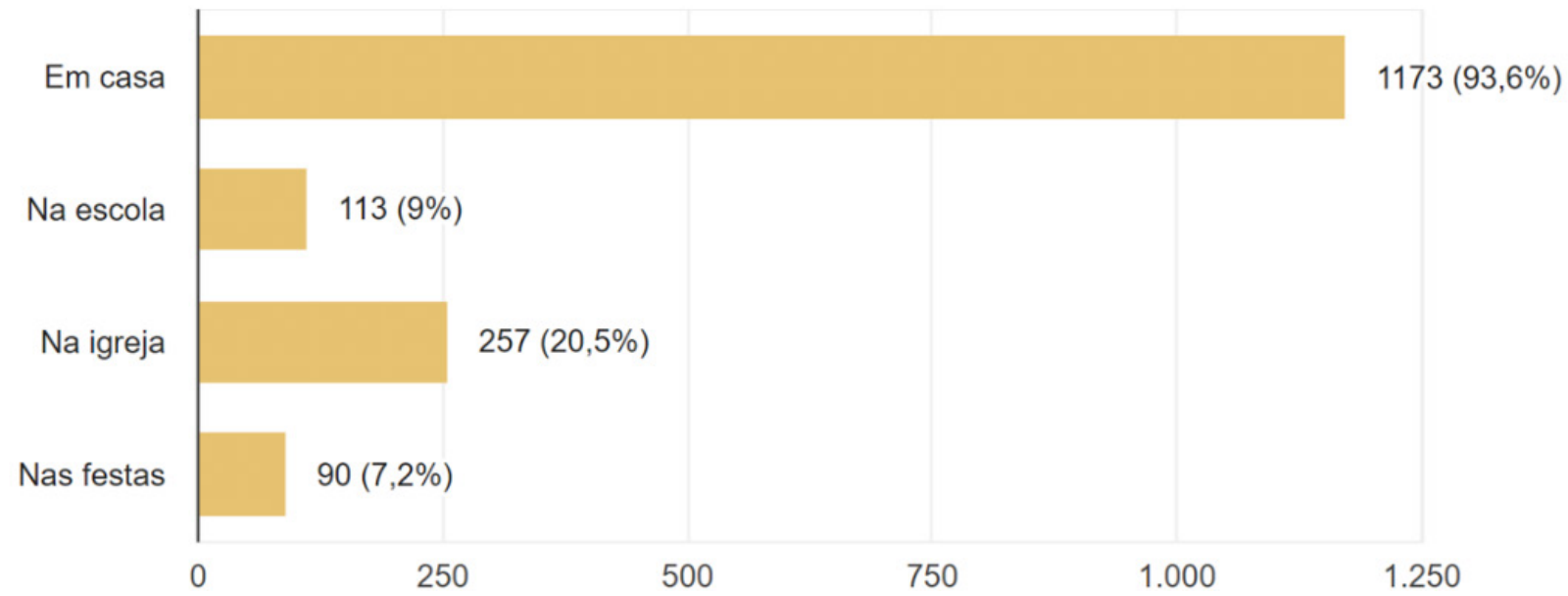

Gráfico 24: Lugar onde canta (anos finais - 1.253 respostas). Fonte: elaborado pelos autores.

Destacamos, nos gráficos 23 e 24, o papel da residência e das manifestações religiosas de cada aluno na interação com o primeiro instrumento musical, que é a voz humana. Ressaltamos a necessidade de motivar, valorizar e englobar a voz, que é apontada em Houlahan e Tacka (2015) como o caminho mais rápido para a expressão musical do aluno no campo da educação 
básica e, mais precisamente, nas ações que englobam o subcampo da educação musical no âmbito escolar.

Kodály estava convencido que o canto é o caminho mais direto para uma educação musical. Cantar requer internalização do som e fornece participação imediata na experiência musical. Sendo a voz humana o mais intimo de todos os instrumentos e o ouvido interno sendo mais facilmente desenvolvido através desse meio pessoal, a voz é o ponto de partida mais lógico (Houlahan; Tacka, 2015, p. 22, tradução nossa).

\section{CONCLUSÕES}

A partir da análise do papel da escola no desenvolvimento das dimensões da musicalidade, podemos notar que o desenvolvimento do subcampo da educação musical se mostra deficiente no campo da educação básica. Constatamos essa situação por meio do papel de destaque na formação do gosto musical exercido pela residência e pelas manifestações religiosas nas quais os alunos se inserem desde os anos iniciais, podendo esse papel permanecer relevante até os anos finais ou quem sabe até a idade adulta.

Percebemos também o papel das ferramentas de streaming, entre as quais o YouTube se destaca, na difusão de material que pode reforçar o direcionamento preexistente do aluno, tendo em vista que as indicações que a própria plataforma faz ao público se relacionam diretamente com o seu histórico de visualizações.

Notamos ainda que um dos papéis da escola é o de contribuir na formação do gosto musical diversificado dos alunos. Incentivamos a interligação entre a vivência cotidiana das crianças no ambiente escolar com os capitais das demais instituições e as ferramentas de streaming que já fazem parte do seu cotidiano.

É uma situação em que o poder simbólico dos docentes pode dialogar com o capital sociocultural preexistente dos discentes. Apontamos o desenvolvimento das dimensões da musicalidade como um caminho possível para interligar diversas ações e aproximar os alunos do fazer artístico-musical de forma direta, objetiva e lúdica.

\section{REFERENCIAS}

ARROYO, Margarete. Escola, juventude e música: tensões, possibilidades e paradoxos. Em Pauta, Porto Alegre, v. 18, n. 30, p. 5-39, 2007.

BRASIL. Ministério da Educação. Base nacional comum curricular. Brasília: MEC, 2017. Disponivel em: http://basenacionalcomum.mec.gov.br/images/ BNCC_EI_EF_110518_versaofinal_site.pdf. Acesso: 18 ago. 2020. 
FONTERRADA, Marisa Trench de Oliveira. De tramas e fios: um ensaio sobre música e educação. 2. ed. São Paulo: Unesp; Rio de Janeiro: Funarte, 2008.

HOULAHAN, Micheál; TACKA, Philip. Kodály today. New York: Oxford University Press, 2015.

MATON, Karl. Habitus. In: GRENFELL, Michael (ed.). Pierre Bourdieu: conceitos fundamentais. Tradução: Fábio Ribeiro. Petrópolis: Vozes, 2018. p. 73-94.

SETTON, Maria da Graça Jacintho. A teoria do habitus em Pierre Bourdieu: uma leitura contemporânea. Revista Brasileira de Educação, Rio de Janeiro, n. 20, p. 60-70, ago. 2002. Disponivel em: http://www.scielo.br/scielo. php?script=sci_arttext\&pid=S1413-24782002000200005\&lng=en\&nrm=iso. Acesso em: 25 ago. 2020.

SOMBRA, Daniel do Nascimento. Educação musical soando na escola: transitando entre turno e contraturno numa escola de Caucaia/CE. 2018. Dissertação (Mestrado em Artes) - Instituto de Cultura e Arte, Universidade Federal do Ceará, Fortaleza, 2018. Disponivel em: http://www.repositorio. ufc.br/handle/riufc/35010. Acesso em: 18 ago. 2020.

TEÓFILO, Israel Kleber de Oliveira. As narrativas de vida dos alunos como ferramenta pedagógica em música: primeiras considerações. In: SEMINÁRIO DE PRÁTICAS EDUCATIVAS, MEMÓRIAS E ORALIDADES, 6., 2019, Fortaleza. Anais [...]. Fortaleza: Eduece, 2019. p. 366-371. Disponivel em: https:/ / 2fd68c30-e174-4136-bc09-870dfa92ce62.filesusr.com/ ugd/87a2c1_d25b03f614874ae29202e57fd218ec76.pdf. Acesso em: 18 ago. 2020. 
Daniel do Nascimento Sombra é mestre em Artes pela Universidade Federal do Ceará (UFC). Graduado em Licenciatura em Música pela Universidade Estadual do Ceará (UECE). Técnico em Regência Coral (Curso de Extensão em Música - UFC) e técnico em Eletrotécnica pelo Centro Federal de Educação e Tecnológica do Ceará (CEFET-CE). É professor nomeado de música do município de Caucaia desde janeiro de 2011. Durante o ano de 2020 atuou no Núcleo de Educação Musical e Artes, vinculado à Diretoria de Ensino da Secretaria de Educação de Caucaia, desenvolvendo atividades de formação continuada e oferecendo sugestões de videoaulas autorais em parceria com colegas da mesma e de outras linguagens artísticas, além de sugestões de atividades a serem aplicadas em todo o município de Caucaia. Hoje, continua desenvolvendo suas atividades de docência embasadas no fazer musical junto aos alunos e tendo o processo de alfabetização musical para crianças, jovens e adultos como pesquisa constante. https://orcid.org/0000-0002-3761-5477

Israel Kleber de Oliveira Teófilo é mestre em Artes pela Universidade Federal do Ceará (UFC). Especialista em Artes com ênfase em Música pela Universidade Estadual do Ceará (UECE). Graduado em Licenciatura em Música na UECE. Graduando em Pedagogia na UECE. Técnico em Música pelo Instituto Federal de Educação, Ciência e Tecnologia do Ceará (IFCE). Tendo atuado em diversos contextos educacionais e com diferentes faixais etárias, ministra aulas de música desde 2010 e aulas de arte desde 2014. Ministra oficinas e palestras sobre educação musical e criatividade para professores atuantes e em formação. Foi técnico do Núcleo de Educação Musical e Artes e formador dos professores de arte da Secretaria Municipal de Educação de Caucaia. É professor efetivo de música de uma escola da Prefeitura Municipal de Caucaia, onde idealizou e desenvolve o Projeto Som Criativo: experiências-artístico musicais. Dedica-se a pesquisa nas áreas de educação musical, arte-educação e formação de professores. https://orcid.org/0000-0002-6224-732 